\title{
THE INFLUENCE OF HOTEL ATTRIBUTES ON BRAND ATTACHMENT AND POST-CONSUMPTION OUTCOMES: THE MEDIATING EFFECTS OF BRAND CREDIBILITY
}

\author{
Nadzirah Rosli \\ University of Malaya \\ Norbani Che-Ha* \\ University of Malaya \\ Ezlika Mohd Ghazali \\ University of Malaya
}

\begin{abstract}
This research examine the mediating role of brand credibility between the relationship of hotel attributes and brand attachment that will to lead to post-consumption outcomes. We also examine how hotel attributes contributes to the brand attachment and post-consumption outcomes. Based on the mean-end chain theory, it explores the relationship among six constructs; hotel attributes, brand credibility, brand attachment and postconsumption outcomes (i.e., satisfaction, revisit intention and word-of-mouth). Partial Least Squares Structural Equation Modelling (PLS-SEM) approach was deployed to validate the research model. The result indicates brand credibility fully mediates the relationship between hotel attributes and brand attachment. Subsequently, brand credibility and brand attachment are found to be significantly linked with postconsumption outcomes. The result offers implications for hotelier and direction for future research.
\end{abstract}

Keywords: brand credibility; Hotel attributes; Brand attachment; Post-consumption outcomes; Satisfaction; Revisit intention; Word-of-mouth; Malaysian hotel

Received: 18 October 2018

Accepted: 8 May 2019

\section{INTRODUCTION}

Nowadays, tourism industry is becoming popular worldwide. The hospitality industry's rapid development has resulted in competitive rivalry between hotels over attracting customers to stay and use their facilities (Shafaei \& Mohamed, 2015; Luturlean et al, 2018). Thus, understanding the needs, interests and behaviours of different tourist markets plays an important role in attracting them to destinations.

The world's Muslim population is approximately at 1.8 billion and rising every day. This market is estimated to be worth $\$ 2.1$ trillion (World Halal Summit, 2014). These estimates indicate that

\footnotetext{
* Corresponding Author: Norbani Che-Ha, Faculty of Business and Accountancy, University of Malaya, 50603 Kuala Lumpur, Malaysia. Email: norbanicheha@um.edu.my
} 
the demand to cater for Muslim needs are burgeoning, which proven based on the rising of Muslim consumers' purchasing power. The increase of Islamophobia has make Muslim people feel unsafe, targeted and prefer to congregate within the Muslim sphere. These days, Muslim tourists are changing their travel habit and redirecting their choices towards Muslim-friendly destinations to guarantee a genuine feeling of safety and freedom to be themselves (Kessler \& Kessler, 2015). The increase on scepticism about corporation and their branding effort have raised some concerns. People by nature generally want to avoid risk and seek safety. We could have been experienced getting something that was far from what we have expected from a hotel. For instance, we expected a modern design room equipped with comfortable bed and clean bathroom. Instead, we get an oldfashioned room with squeaking bed and mouldy bathroom. This misleading information may lessen the hotel's (brand) credibility since it is not what the consumer perceived.

Nowadays, both experienced and novice consumer rely heavily on the information available on the Internet when choosing hotel. Research has shown that website contents have direct influences on consumer preferences and purchase decisions, particularly photo image (Kuo, Zhang, \& Cranage, 2015; Jeong \& Choi, 2004; Ting et al., 2012). Some hotels use "perfect" photos and deceptive information to make their properties look more appealing to customers. The credibility of these hotel become questionable. As of October 2014, TripAdvisor.com have generated over 5600 results from the keyword search of "misleading photos", whereby as of May 2019, the search results have increased to 14,100 which suggests that these phenomena are not uncommon (Kuo et al., 2015).

The growth of uncertainty towards products and services have raised an alarm to most Muslim consumers in Malaysia. Consumers nowadays are concern about the credibility of the product prior to make their decision as they have become more sensitive towards source of their everyday consumption. Despite growing interest in brand credibility, relatively little is known about how brand credibility influences consumer behaviour outcomes in the service domain (Tae \& King, 2011; Jeng, 2016; Sheeraz, Iqbal, \& Ahmed, 2012; Wang \& Yang, 2010). The results of this study may provide new insights to hotel mangers on how the credibility of the hotel may lead to a longterm relationship between the hotel brand and consumer which will lead towards a sustainable leading position in the industry (So \& King, 2010).

This research proposes a framework that contributes to literature in two ways. First, the study examines the mediating role of brand credibility between the relationship of hotel attributes and brand attachment that will then lead to post-consumption outcomes. Second, we will examine how hotel attributes contributes to the brand attachment and post-consumption outcomes.

\section{LITERATURE REVIEW}

The study is based on the mean-end chain (MEC) theory (Gutman, 1982). The MEC theory views consumers as goal-oriented decision makers, who choose to perform behaviours that seem most likely to lead desired outcomes. The result is a value chain linking product/service attributes to its functional consequences, followed by its emotional consequences and underlying personal value.

In this study, following Keller and McGill (1994), the attributes would include the tangible and intangible features of a service provided by a hotel which include benefits, functions and uses. 
Furthermore, consequences refer to the outcomes associated with purchasing and consuming/experiencing a product or service (Goldenberg, Klenosky, O’Leary, \& Templin, 2000). In this study, the consequence include emotional experiences in forms of the attachment that occur between the hotel and the consumer. Value on the other hand are highly abstract consequences that summarize desired end-states of being (Goldenberg et al., 2000).

To exploit the potential of MEC theory, we also extended and adapted other factor (i.e. brand credibility) that might also effect the initial interrelationship between attributes, consequences and value. This factor was referred as some forms of business-to-customer (B2C) marketing (Ryan, 2012). According to Ryan (2012), credibility is a major factor in both B2B and B2C marketing. Typically, consumers will move on to competitor if consumer does not see a brand as credible resources (Ryan, 2012). Past literatures also suggests that there is positive link between hotel attributes and brand credibility, especially in hospitality industry (Jeng, 2016). Therefore, this study will examine the mediating effect of brand credibility and the relationship of hotel attributes and brand attachment on post-consumption outcomes.

\subsection{Hotel Attributes (HA)}

Product attributes are defined as properties or characteristics of a product which are intrinsic to it, or attached to it and concrete, observable, objectively measurable and relevant to choose among alternatives (Tsung, Day \& Mackay, 1988). According to Wuest et al. (1996), perceptions of hotel attributes is the degree to which travellers find various services and facilities are important in promoting their satisfaction with hotel stays (Poon \& Low, 2005). In other word, hotel attributes or the service and facilities offered by a hotel, are those features that lead consumers to choose one product over others (Lewis, 1983). The current study conceptualized hotel attributes as the degree to which tourist find various services and facilities offered by the hotel are important during their hotel stay.

\section{2. $\quad$ Brand Credibility (BC)}

Typically, a brand stands for a fixed amount of a fixed quality for a fixed price in order to simplify purchase decision (Maathuis, Rodenburg \& Sikkel, 2004). However, consumers also do take an interest in evaluating the credibility of a product/service. Brands are built on credibility. People's readiness to buy products, services or to trust someone depends on credibility (Maathuis et al., 2004). In brand management literatures, credibility is one of the most important characteristics of a brand (Aaker \& Davis, 2000; Keller, 2000 as cited in Maathuis et al., 2004).

According to Erdem and Swait (1998), when market is characterized as imperfect (consumers cannot readily evaluate the product quality) and asymmetric information (firms know better about the quality of the products they sell than consumers), it is important for firm to convey credible information to consumers. In other words, the information that is communicated by a firm to its consumer about their brand's position should be perceived as truthful and dependable. As a result, the credibility would prompt consumer confidence in a firm's product claims. A credible brand minimizes risk and increases consumer confidence. Customer would attempt to re-purchase if they believe that a brand is delivering on its promises (trustworthiness). 
Brand credibility is defined as to which extent people believe in a product/service, based on the provided information (Erdem \& Swait, 2004; Baek \& King, 2011). There are three components of the credibility concepts. (Hovland et al, 1953; Sternthal \& Craig, 1982; Keller \& Aaker, 1992; 1997; Maathuis, 1999):

i. Reliability/trustworthiness, the degree to which an object is considered to be an honest source of information, products, services, and other matters.

ii. Expertise, the degree to which an object has relevant knowledge and skills.

iii. Attractiveness, the degree to which an object is valued by sympathetic behaviour, ambition, perseverance, smartness and other personality-like characteristics.

Following Erdem and Swait (2004), current study conceptualized brand credibility as to which extent tourist believe in products or services offered by a hotel based on the provided information.

\subsection{Brand Attachment (BA)}

Brand attachment is defined as the extent to which an object which is owned, expected to be owned or previously owned by an individual is used to maintain his/her self-concept (Ball \& Tasaki, 1992). The marketing literatures describes brand attachment as the consumers' emotional predisposition in the long term toward a brand (Ghose \& Lowengart, 2013; Heilbrunn, 2001; Lacoeuilhe, 1997; Sikkel, 2013). Following Thompson et al. (2005), it is conceptualized as the emotional bonding, the degree of affection, passion and the connection to measure attachment toward specific brand.

\subsection{Post-Consumption Outcomes}

Previous studies that examine about revisit intention have considered tourist satisfaction as a backbone in most of their models (Jang \& Feng, 2007; Baker \& Crompton, 2000; Kozak, 2001; Oppermann, 2000). However, several studies suggest that simply satisfying customers may not be sufficient to create customer loyalty (Cronin \& Taylor, 1992). Even when high service quality is provided and customer is satisfied, it does not necessarily mean that this customer will return (Kotler et al., 2003, Reid \& Bojanix, 2009; Zeithaml et al., 2006). Further, Um, Chon and Ro (2006) and Bigne et al. (2009), argue that even the satisfied customers might not use the services of the same organization because of the highly competitive market in the tourism industry. They tend to explore other available substitutions. Gitelson and Crompton (1984), further exerts that many satisfied customer did not intend to return because they seek for new experience in their future potential trip. Dolnicar, Coltman and Sharma (2015), in their study conclude that satisfaction play only a minor role as factors affecting tourists' intention to return.

This finding implies that the link between satisfaction and behavioural intention is complex and there are number of possible reasons why high levels of satisfaction do not always lead to the expected positive behavioural intention. Hence, we would undertake brand attachment and brand credibility to directly affect satisfaction, revisit intention and word-of-mouth, individually. 


\subsubsection{Satisfaction (SAT)}

Oliver (1997) considered satisfaction as consumer's fulfilment response and defined it as the summary of psychological state resulting when the emotion surrounding disconfirmed expectations is coupled with a consumer's prior feelings about the consumer experience. In addition, Oliver (1997) also referred customer satisfaction as a judgement that a product or service feature, or the product or service itself, provides a pleasurable level of consumption related fulfilment, either under fulfilment or over fulfilment. Baker and Crompton (2000) define tourist satisfaction as an individual emotional state after experiencing the trip. The current study conceptualized satisfaction as a consumer's fulfilment response and their individual state after experiencing a stay.

\subsubsection{Revisit Intention (RVI)}

The concept of revisit intention derives from behavioural intention, which can be defined as the intention to plan to perform a certain behaviour, for example, the repurchase of tourism services or revisiting a destination (Kashyap \& Bojanic, 2000). Intention to revisit a tourism destination is defined as an individual's readiness or willingness to make a repeat visit to the same destination, providing the most accurate prediction of a decision to revisit, e.g. purchase of a vacation package to the same destination (Han \& Kim, 2010). Cole and Scott (2004) define revisit intention as the desire to visit, in a specific timeframe, a prior destination for a second time. Based literatures, we conceptualized revisit intention as the individual readiness or willingness to make a repeat visit to the same hotel.

\subsubsection{Word-of-Mouth (WOM)}

Word-of-mouth is understood as any positive or negative statement made by potential, actual or former customers about a product/company, which is made available through offline or online channel (Hennig-Thurau et al, 2004). Speaking about a brand to others is considered an important part of an individual's identity construction (Holt, 1997). It has been shown to influence other people's purchase behaviour (Kim, Ng \& Kim, 2009).

\section{HYPOTHESIS DEVELOPMENT}

In recent years, marketing scholars have increasingly recognized the important role of emotion in consumer decision-making (Gaur, Herjanto \& Makkar, 2014). According to Japutra, Ekinci and Simkin (2016), research on brand attachment is relatively new, as its conceptualization is still developing. Park et al. (2010) also noted that further research is needed on better understanding of antecedents and consequents of brand attachment across many domains. It is evidence that brand elements such as store offer resources to build brand attachment (Park et al., 2010). Moreover, store attributes have shown to positively influence the consumer's emotional attachment (Vlachos, Theotokis, Pramatari, \& Vrechopoulos, 2010). The current study attempts to examine the applicability of the same concept in the hotel setting, following hypothesis is advanced:

H1: Hotel attributes positively influence brand attachment in Muslim tourists' hotel choice. 
In the literature on brand management, credibility is perceived as one of the most important characteristics of a brand (Aaker \& Davis, 2000; Keller, 2000 as cited in Maathuis et al., 2004). Some studies have examined the relationship between brand credibility and consumers' brand purchase intention (Erdem \& Swait, 1998; Erdem \& Swait, 2004; Jeng, 2016; Maathuis et al., 2004; Sheeraz et al., 2012; Spry et al., 2011; Tae \& King, 2011; Wang \& Yang, 2010).

Though there are extant literatures of hotel attributes in determining hotel choice decision (Rhee \& Yang, 2015; Dortyol et al., 2014), satisfaction and guest intention (Worsfold et al., 2016; Ryu et al., 2012), based on author best knowledge, studies relating hotel attributes and brand credibility is less common and insufficient. Baek and King (2011) attempted to investigate whether brand credibility is applicable to service categories and they suggested that utilitarian services, unlike hedonic services, increase brand credibility's impact on purchase intention. If consumer believe that a firm can deliver on its promise of service quality, they tend to have higher affective commitment, since trust in that firm justifies consumers positive feelings and reliance towards the firm (Erkman \& Hancer, 2015; Sweeney \& Swait, 2008). Some prior literatures evidenced the effect of trustworthiness on affective commitment (Wang, 2014; Jeng, 2016). In accordance with the objectives of current study, we postulate that when a hotel has a higher credibility, it will intensify the relationship between hotel attributes and brand attachment, as consumer will tend to develop higher attachment towards to hotel. Following hypothesis is advanced:

H2: $\quad$ The relationship between hotel attributes and brand attachment is mediated by brand credibility.

Researchers have examined brand attachment in diverse contexts, including repurchase intention (Barreda, Nusair, Okumus, \& Bilgihan, 2013; Baumgarth, 2014; Hew, Badaruddin \& Moorthy, 2017; Lin, Chen \& Hung, 2011). Barreda et al. (2013) revealed that if consumers are attracted to the brand, they would likely to repurchase from a travel brand website and recommend it to others. They also found that the probability that online social network members will repurchase through the online social network website will be increased when they are emotionally connected with the online social network websites. Similar argument was supported by Lin et al. (2011), which suggest that brand attachment has positive influence on repurchase intention. It is suggested that once brand provide consumers with required resources, they believe the brand have personalized meaning and are related to them. The brands offer sensory pleasures to meet the consumer's ego and transform to repurchase intention. Likewise, Baumgarth (2014) also shared the same arguments as others. Furthermore, Yoga (2018) in her study shown a significant influence between the variables of halal awareness, halal logos and food composition on emotional attachments and significant influences also occurred between emotional attachment and repurchase intention. Therefore, it is expected that consumers would more likely to revisit the hotel, if they are emotionally attached to the hotel. The following hypothesis is formed:

H3: Brand attachment positively influence on revisit intention in Muslim tourists' hotel choice.

Besides, brand attachment also has potential influence on satisfaction. According to Matzler, Strobl, Thurner, and Füller (2015), a closer personal bond between customers and a seller could ultimately strengthen customer satisfaction. Similarly, Santouridis and Trivellas (2010) further added that stronger attachment to the services will subsequently increase consumers' satisfaction with the services. This argument also coincides with study by Lee (2016) which evidenced the 
positive relationship between brand attachment and satisfaction. Acting from these statements, it is estimated that consumers get higher level of satisfaction when they are deeply attached to a hotel brand. The following hypothesis is formed:

H4: Brand attachment positively influence on satisfaction in Muslim tourists' hotel choice.

The important role of emotions in communication process have been increasingly noticed by scholars studying interpersonal relationship (Guerrero \& Afifi, 1999; Planalp, 1993). As put forth by Chen, Dwyer and Firth (2015), brand attachment is found to be significantly affecting WOM behaviours. In their study, they found that when the customers strongly identify a brand, they are more likely mentioning this brand in conversation and on the social media. Therefore, it is expected that if consumers are highly attached to the hotel brand, they will more likely to engage in wordof-mouth. Thus, it is hypothesized that:

H5: Brand attachment positively influence on WOM in Muslim tourists' hotel choice.

Some scholars suggest that trust, which is one of the components of brand credibility is the dominant antecedent of repurchase intentions (Doney \& Cannon, 1997). Similarly, trust is also found to be an important role in repurchase intention for regular customers (Garbarino \& Johnson, 1999). Ranaweera and Prabhu (2003) in their study found that trust have a strong positive effect on customer retention. Likewise, Zboja and Voorhees (2006) also found that trust was clearly linked to consumer's satisfaction and repeat purchase intentions. In the context of organizational, Gupta and Saini (2018) evidenced the importance of perceived credibility on influencing job seeker's intention to apply. Therefore, based on these preceding literatures, it is proposed that:

H6: Brand credibility positively influence revisit intention in Muslim tourists' hotel choice.

If consumers believe that the firm (i.e. the hotel) is capable of delivering on its promises (i.e. it has the expertise to perform well), it should directly contribute to an increase in satisfaction. Gwinner, Gremler and Bitner (1998); Harris and Goode (2004); as well as Hennig-Thurau, Gwinner and Gremler (2002) found support for the effect of trust in the service provider on satisfaction. Similarly, the business or service provider expertise which include aspects such as technical knowledge, ability to demonstrate knowledge and competence and proof of expertise in the field, has been found to increase customer satisfaction (Franco, 1990; Wray, Palmer \& Bejou, 1994). Furthermore, the research findings from Othman, Kamarohim, and Nizam (2017), shown that there is positive influence of brand credibility, perceived quality and perceived value on customer satisfaction. Findings also show that information quality predicts source credibility, customer satisfaction, and website quality (Filieri, Alguezaui \& McLeay, 2015). Thus, the following hypothesis is advanced:

H7: Brand credibility positively influence satisfaction in Muslim tourists' hotel choice. 
High trustworthiness should also lead to high sentiments of loyalty commitment, since trust of a relational partner justifies customers' positive affect for and reliance on the firm (Sweeney \& Swait, 2008). An important contribution of this effect is "shared experiences". The role of brand credibility is also found to be the main driver of consumer's WOM in marketing (Sallam, 2014). According to Zboja and Voorhees (2006), when consumers have an existing trust in an offline store, they are willing to purchase the product online, willing to spend more time on the websites and willing to recommend that same online store to others. Furthermore, Filieri, Alguezaui and McLeay (2015) found that trust towards consumer generated media influences travel consumers' intention to follow other users' recommendation and foster positive WOM. The following hypothesis is proposed:

H8: Brand credibility positively influence WOM in Muslim tourists' hotel choice.

Figure 1: Research Model

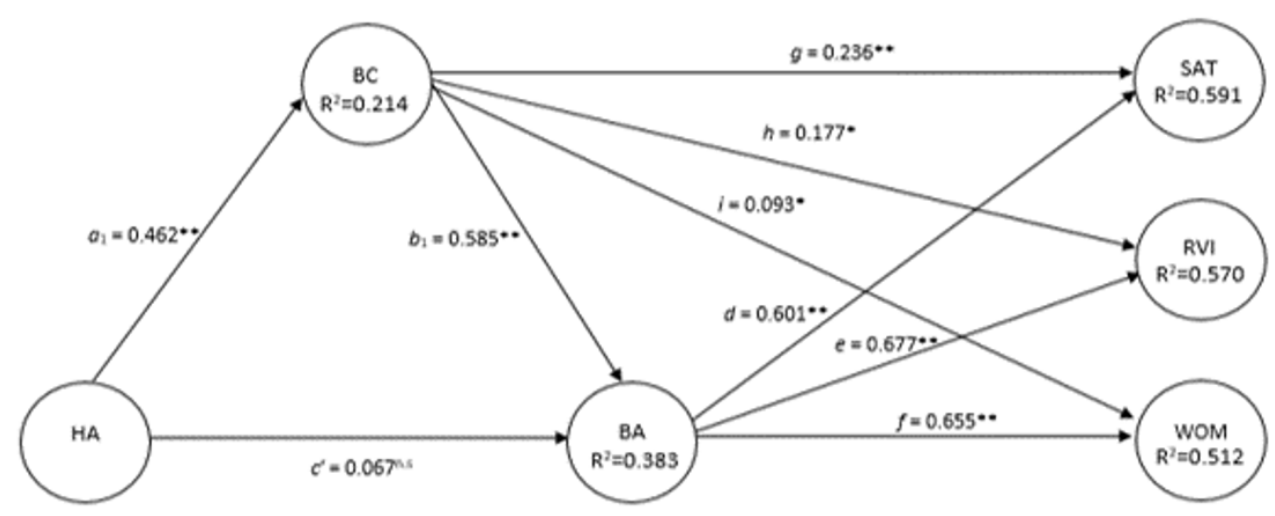

H1: Hotel Attributes $\rightarrow$ Brand Attachment $=\mathrm{c}^{\prime}$

H2: Hotel Attributes $\rightarrow$ Brand Credibility $\rightarrow$ Brand Attachment $=a_{1} b_{1}$

H3: Brand Attachment $\rightarrow$ Revisit Intention $=\mathrm{d}$

$\mathrm{H} 4:$ Brand Attachment $\rightarrow$ Satisfaction $=\mathrm{e}$

$\mathrm{H} 5$ : Brand Attachment $\rightarrow$ WOM $=f$

H6: Brand Credibility $\rightarrow$ Revisit Intention $=\mathrm{g}$

$\mathrm{H} 7:$ Brand Credibility $\rightarrow$ Satisfaction $=\mathrm{h}$

H8: Brand Credibility $\rightarrow$ WOM $=i$

Note: ${ }^{* *} p<0.01,{ }^{*} p<0.05$

\section{RESEARCH METHODOLOGY}

\subsection{Data Collection and Sample}

A survey approach by using self-administered questionnaire was conducted from March 2017 to July 2017. Referring to the estimates provided by the Ministry of Tourism database (Department of Statistics Malaysia, 2018), around 66 million tourists went on domestic overnight trips in 2016; 
but since accurate data as to the location and dispersion of this population were not available, probabilistic sampling technique could not be used. Therefore, a non-probability sampling method namely purposive sampling was used. The unit of analysis was individual Muslim consumers in Malaysia who have stayed in a hotel within the last year. The questionnaires were filled up by the respondents with a cover letter in a face-to-face survey. In the questionnaire, ithe respondents were required to evaluate one of the hotels at which they recently stayed. Hence, the respondents were expected to report with reference to a hotel that they had stayed at recently in order to effectively explore and reflect the research. A total of 474 completed and valid questionnaires were used for the analyses. Specific demographic information is shown in Table 1.

Table 1: Sample Characteristic

\begin{tabular}{llcc}
\hline \hline \multirow{2}{*}{ Gender } & Demographic Characteristics & Frequency & Percent \\
\hline \multirow{2}{*}{ Age } & Male & 254 & 53.6 \\
& Female & 220 & 46.4 \\
\hline & $20-29$ years old & 377 & 79.5 \\
& $30-39$ years old & 56 & 11.8 \\
& $40-49$ years old & 35 & 7.4 \\
& $50-59$ years old & 5 & 1.1 \\
& 60 years old and above & 1 & 0.2 \\
\hline Marital Status & Single & 366 & 77.2 \\
& Married without children & 28 & 5.9 \\
& Married with children & 77 & 16.2 \\
& Divorced/Separated/Widowed & 3 & 0.6 \\
\hline Education & SPM & 34 & 7.2 \\
& STPM/Diploma/College & 123 & 25.9 \\
& Bachelor Degree/Professional Degree & 299 & 63.1 \\
& Postgraduate Degree & 18 & 3.8 \\
\hline Monthly Income & Less than RM1,999 & 254 & 53.6 \\
& RM2,000 - RM3,999 & 137 & 28.9 \\
& RM4,000 - RM5,999 & 53 & 11.2 \\
& RM6,000 - RM7,999 & 14 & 3.0 \\
& RM8,000 - RM9,999 & 8 & 1.7 \\
& RM10,000 and above & 8 & 1.7 \\
\hline \hline
\end{tabular}

\subsection{Measures}

The first part of the questionnaire addressed the respondents' travel behaviour. The second part of the survey asked respondents to rate each of the questions in the hotel attributes instrument adapted from extant literatures using seven-point Likert scale (Battour, Battor \& Bhatti, 2014; Chu \& Choi, 2000; Juwaheer, 2004; Poon \& Low, 2005; Saad, Ali \& Abdel-Ati, 2014). The questionnaire was followed by brand credibility (Erdem \& Swait, 2004; Ohanian, 1990; Wang \& Yang, 2010), brand attachment (Hemsley-Brown \& Alnawas, 2016), and satisfaction (Ryu, Han \& Jang, 2010; Yoon \& Uysal, 2005), revisit intention (Hellier, Geursen, Carr \& Rickard, 2003; Stylos, Bellou, Andronikidis, \& Vassiliadis, 2017) and word-of-mouth (Karjaluoto, Munnukka \& Kiuru, 2016; Kim, Kim \& Kim, 2009). The final part of the survey contained demographic type questions. 


\subsection{Data Analysis}

Our research model was tested using Partial Least Squares (PLS), a variance-based structural equation modeling. As recommended by Hair, Hult, Ringle \& Sarstedt (2017), the PLS was chosen because (1) the research model is complex according to the type of relationship hypothesized (direct and mediation) and (2) formative measured construct as part of the structural model.

\section{RESULTS \& DISCUSSION}

The common method variance was addressed because the data are collected via self-reported questionnaires and both the predictor and criterion variables are obtained from the same person (Podsakoff, Mackenzie, Lee \& Podsakoff, 2003). To address this issue, we used Harman's single factor test (Podsakoff \& Organ, 1986). Results from a factor analysis without rotation found that the first factor only explained 37.85 per cent which is much lower than the majority, indicating method bias is not a serious issue with this study.

\subsection{Reflective Measurement Model}

The assessment of the measurement model for reflective indicators is based on individual item reliability, convergent validity and discriminant validity. Individual item reliability is considered adequate because all the indicators have loadings above 0.70 (Hair, Sarstedt, Hopkins \& Volker, 2014). To assess convergent validity, we examine average variance extracted (AVE) and composite reliability (CR). All latent variables achieve convergent validity given that their AVEs and CRs surpass recommended values of 0.5 level and 0.7 respectively (Table 2).

Then, we assessed the discriminant validity using the Fornell and Larcker (1981) method. Table 3 shown the values in the diagonals are greater than the values in their respective row and column, indicating that the measures used in this study are distinct which demonstrating adequate discriminant validity. We also assesses the discriminant validity through heterotrait-monotrait ratio of correlation. Table 4 shows that all the constructs attain discriminant validity following the HTMT0.90 criterion (Gold, Malhotra \& Segars, 2001), indicating that all the constructs are empirically distinct.

Table 2: Individual Item Reliability and Convergent Validity

\begin{tabular}{llccc}
\hline \hline Construct & Item & Loading & CR & AVE \\
\hline Brand Attachment & BA1 & 0.826 & 0.971 & 0.709 \\
& BA2 & 0.859 & & \\
BA3 & 0.878 & & \\
BA4 & 0.839 & & \\
BA5 & 0.865 & \\
BA6 & 0.844 & \\
BA7 & 0.845 & \\
BA8 & 0.801 & \\
BA9 & 0.875 &
\end{tabular}




\begin{tabular}{|c|c|c|c|c|}
\hline Construct & Item & Loading & CR & AVE \\
\hline & BA11 & 0.845 & & \\
\hline & BA12 & 0.842 & & \\
\hline & BA13 & 0.797 & & \\
\hline & BA14 & 0.794 & & \\
\hline \multirow[t]{10}{*}{ Brand Credibility } & $\mathrm{BC} 1$ & 0.697 & 0.949 & 0.652 \\
\hline & $\mathrm{BC} 2$ & 0.781 & & \\
\hline & $\mathrm{BC} 3$ & 0.827 & & \\
\hline & $\mathrm{BC} 4$ & 0.821 & & \\
\hline & $\mathrm{BC} 5$ & 0.827 & & \\
\hline & BC6 & 0.833 & & \\
\hline & $\mathrm{BC} 7$ & 0.812 & & \\
\hline & $\mathrm{BC} 8$ & 0.831 & & \\
\hline & BC9 & 0.819 & & \\
\hline & $\mathrm{BC} 10$ & 0.813 & & \\
\hline \multirow[t]{4}{*}{ Satisfaction } & BOSAT1 & 0.930 & 0.967 & 0.878 \\
\hline & BOSAT2 & 0.951 & & \\
\hline & BOSAT3 & 0.945 & & \\
\hline & BOSAT4 & 0.922 & & \\
\hline \multirow[t]{4}{*}{ Revisit Intention } & BORVI1 & 0.924 & 0.959 & 0.853 \\
\hline & BORVI2 & 0.938 & & \\
\hline & BORVI3 & 0.926 & & \\
\hline & BORVI4 & 0.906 & & \\
\hline \multirow[t]{4}{*}{ Word-of-Mouth } & BOWOM1 & 0.932 & 0.965 & 0.872 \\
\hline & BOWOM2 & 0.937 & & \\
\hline & BOWOM3 & 0.935 & & \\
\hline & BOWOM4 & 0.930 & & \\
\hline
\end{tabular}

Notes: composite reliability (CR); average variance extracted (AVE)

Table 3: Discriminant Validity (Fornell and Larcker)

\begin{tabular}{lccccc}
\hline \hline Construct & BA & BC & RVI & SAT & WOM \\
\hline 1. Brand Attachment & & & & & \\
2. Brand Credibility & 0.643 & & & & \\
3. Revisit Intention & 0.783 & 0.563 & & & \\
4. Satisfaction & 0.774 & 0.632 & 0.841 & & \\
5. Word-of-Mouth & 0.739 & 0.520 & 0.896 & 0.817 & \\
\hline \hline
\end{tabular}

Table 4: Discriminant Validity (Heterotrait-Monotrait - HTMT)

\begin{tabular}{lcccccc}
\hline \hline Construct & $\mathbf{1}$ & $\mathbf{2}$ & $\mathbf{3}$ & $\mathbf{4}$ & $\mathbf{5}$ & $\mathbf{6}$ \\
\hline 1. Brand Attachment & $\mathbf{0 . 8 4 2}$ & & & & & \\
2. Brand Credibility & 0.616 & $\mathbf{0 . 8 0 7}$ & & & & \\
3. Hotel Attributes & 0.337 & 0.462 & NA & & & \\
4. Revisit Intention & 0.749 & 0.534 & 0.264 & $\mathbf{0 . 9 2 3}$ & & \\
5. Satisfaction & 0.746 & 0.606 & 0.339 & 0.798 & $\mathbf{0 . 9 3 7}$ & \\
6. Word-of-Mouth & 0.712 & 0.496 & 0.318 & 0.848 & 0.779 & $\mathbf{0 . 9 3 4}$ \\
\hline \hline
\end{tabular}




\subsection{Formative Measurement Model}

We examine the formative measurement models following recommendation by Hair et al. (2017). Firstly, the convergent validity was assessed by correlating the formatively measured construct with a reflective measure of the same construct, known as redundancy analysis (Chin, 1998). Ideally a magnitude of 0.80 , but at a minimum of 0.70 and above is desired, which translate into $R^{2}$ value of 0.64 , or at least 0.50 (Hair et al., 2017). The result shows that the redundancy analysis of hotel attributes (HA) yield estimates of 0.852 , which translate into $R^{2}$ value of 0.762 . Thus, all formatively measured constructs exhibit convergent validity.

Secondly, the collinearity was assessed. It suggests that multicollinearity is a concern if the VIF is higher than 10; however, multicollinearity poses more of a problem (Petter et al., 2007). Following threshold value of 5 as recommended by Hair, Ringle \& Sarstedt (2011), as observed in Table 5, all VIF values are less than 5, indicating that multicollinearity is not severe.

Thirdly, the significance and relevance of the formative indicators were assessed via the outer weight. While no minimum threshold values for formative indicator weights have been established (Rai, Patnayakuni, \& Seth, 2006), a high indicator weight suggests that the indicator is making a substantive contribution to the formative construct (Diamantopoulos, 2006). Diamantopolous and Winklhofer (2001) suggest that if any of the item weighting for formative construct measures are nonsignificant, it may be appropriate to remove nonsignificant indicators (one at a time) until all paths are significant and a good fit is obtained. However, it is important to ensure that the construct is still measuring the entire domain and the content validity is preserved when removing measures. Because of this, some researchers suggest retaining nonsignificant indicators to retain content validity (Bollen \& Lennox, 1991).

As observed in Table 5, most items surpassed the weight estimation which should be greater than 0.10 or 0.20 (Chin, 1998; Lohmöller, 1989), except for HA3, HA6, HA12, HA13, HA14, HA15, HA16, HA19. However, we should not interpret nonsignificant indicator weights as indicative of poor measurement quality. Rather, we should also consider a formative indicator's absolute contribution to its construct which is given by the outer loading (Hair et al., 2016). An indicator should be interpreted as absolute important when its outer weight is nonsignificant and its outer loading is above 0.50 (Hair et al., 2017). HA15 is retained since its outer loading is above recommended value. When an indicator has a nonsignificant weight and the outer loading is below 0.50 , researchers should decide whether to retain or delete the indicator by examining its theoretical relevance and potential content overlap with other indicators of the same construct (Hair, Hult, Ringle \& Sarstedt, 2017). We decided to retained HA3, HA6, HA12, HA13, HA16 and HA19 since it has important contribution to construct whereby dropping the items may change what the construct measuring (Diamantopoulos \& Winklhofer, 2001). These items also were strongly supported by expert assessment. HA14 is omitted based on the consideration that its content may overlap with other indicator (eg; HA13). 
Figure 2: Redundancy Analysis Assessment of Formative Measurement Model

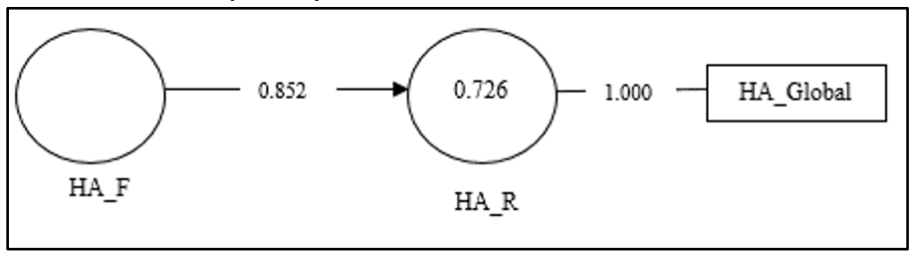

Table 5: Formative Construct Measurement Model

\begin{tabular}{lcccc}
\hline \hline Construct & Item & Weights & Loading & VIF \\
\cline { 2 - 4 } Hotel Attributes & HA1 & 0.331 & 0.634 & 1.922 \\
HA2 & 0.120 & 0.475 & 2.691 \\
HA3 & 0.057 & 0.312 & 2.365 \\
HA4 & 0.484 & 0.538 & 1.773 \\
HA5 & -0.297 & 0.301 & 2.508 \\
HA6 & -0.033 & 0.427 & 1.904 \\
HA7 & -0.138 & 0.346 & 2.139 \\
HA8 & 0.152 & 0.480 & 2.429 \\
HA9 & 0.192 & 0.480 & 2.254 \\
HA10 & 0.211 & 0.490 & 3.058 \\
HA11 & -0.134 & 0.377 & 3.567 \\
HA12 & -0.092 & 0.370 & 3.233 \\
HA13 & -0.016 & 0.378 & 2.178 \\
HA14 & -0.006 & 0.347 & 2.484 \\
HA15 & 0.049 & 0.505 & 1.806 \\
HA16 & 0.063 & 0.318 & 1.894 \\
HA17 & -0.315 & 0.140 & 2.161 \\
HA18 & -0.125 & 0.260 & 1.530 \\
HA19 & 0.035 & 0.475 & 1.761 \\
HA20 & 0.595 & 0.750 & 1.995 \\
\hline \hline
\end{tabular}

\subsection{Structural Model}

To evaluate the structural models' predictive power, we calculated the $R^{2}$. We used Cohen (1988) guidelines which are $0.02,0.15$ and 0.35 respectively represent small, medium and large effects (Cohen, 1988). As observed in Table 6, all the relationship showed substantive impact with large effects. Using a bootstrapping technique with resampling of 5000, the path estimates and t-statistics were calculated for the hypothesized relationships.

The direct effect between hotel attributes and brand attachment is not significant $(\beta=0.067$, $\mathrm{p}=1.232$ ). Thus, $\mathrm{H} 1$ is not supported. Meanwhile, all other hypotheses were found to be significant. Brand attachment are positively related with satisfaction $(\beta=0.601, p<0.000)$, revisit intention $(\beta$ $=0.677, \mathrm{p}<0.000)$ and WOM $(\beta=0.655, \mathrm{p}<0.000)$. Brand credibility are also found to be positively related with satisfaction $(\beta=0.236, \mathrm{p}<0.000)$, revisit intention $(\beta=0.117, \mathrm{p}<0.05)$ and WOM $(\beta=0.093, \mathrm{P}<0.05)$. Thus, H3, H4, H5, H6, H7 and H8 were supported. 
Table 6: Hypothesis Testing

\begin{tabular}{|c|c|c|c|c|c|c|c|c|c|c|}
\hline Hypothesis & $\begin{array}{l}\text { Direct } \\
\text { Effects }\end{array}$ & $\begin{array}{c}\text { Std } \\
\text { Beta }\end{array}$ & $\begin{array}{c}\text { Std } \\
\text { Error }\end{array}$ & $\begin{array}{c}\mathrm{t}- \\
\text { value }\end{array}$ & $\begin{array}{c}\text { p- } \\
\text { value }\end{array}$ & $f^{2}$ & $\mathbf{L L}$ & $\mathbf{U L}$ & $R^{2}$ & $Q^{2}$ \\
\hline H1 (c') & $\begin{array}{l}\mathrm{HA} \rightarrow \\
\mathrm{BA}\end{array}$ & 0.067 & 0.054 & 0.054 & $1.232^{\mathrm{n} . \mathrm{s}}$ & 0.006 & -0.041 & 0.138 & 0.383 & 0.252 \\
\hline $\mathbf{a}_{1}$ & $\begin{array}{l}\mathrm{HA} \rightarrow \\
\mathrm{BC}\end{array}$ & 0.462 & 0.041 & 11.319 & $0.000 * *$ & 0.272 & 0.363 & 0.504 & 0.214 & 0.127 \\
\hline$b_{1}$ & $\begin{array}{l}\mathrm{BC} \rightarrow \\
\mathrm{BA}\end{array}$ & 0.585 & 0.041 & 14.235 & $0.000 * *$ & 0.437 & 0.526 & 0.659 & & \\
\hline H3 (d) & $\begin{array}{l}\mathrm{BA} \rightarrow \\
\mathrm{SAT}\end{array}$ & 0.601 & 0.053 & 11.295 & $0.000 * *$ & 0.547 & 0.505 & 0.682 & 0.591 & 0.486 \\
\hline H4 (e) & $\begin{array}{l}\mathrm{BA} \rightarrow \\
\mathrm{RVI}\end{array}$ & 0.677 & 0.050 & 13.618 & $0.000 * *$ & 0.662 & 0.591 & 0.756 & 0.570 & 0.456 \\
\hline H5 (f) & $\begin{array}{l}\mathrm{BA} \rightarrow \\
\mathrm{WOM}\end{array}$ & 0.655 & 0.052 & 12.497 & $0.000 * *$ & 0.544 & 0.562 & 0.735 & 0.512 & 0.419 \\
\hline H6 (g) & $\begin{array}{l}\mathrm{BC} \rightarrow \\
\mathrm{SAT}\end{array}$ & 0.236 & 0.051 & 4.617 & $0.000 * *$ & 0.084 & 0.152 & 0.321 & & \\
\hline H7 (h) & $\begin{array}{l}\mathrm{BC} \rightarrow \\
\mathrm{RVI}\end{array}$ & 0.117 & 0.056 & 2.077 & $0.019 *$ & 0.020 & 0.027 & 0.213 & & \\
\hline H8 (i) & $\begin{array}{l}\mathrm{BC} \rightarrow \\
\mathrm{WOM}\end{array}$ & 0.093 & 0.056 & 1.645 & $0.050^{*}$ & 0.011 & 0.001 & 0.186 & & \\
\hline
\end{tabular}

Notes: HA: Hotel Attributes; BA: Brand Attachment; BC: Brand Credibility; SAT: Satisfaction; RVI: Revisit Intention; WOM: Word-of-Mouth

$* * \mathrm{p}<0.01, * \mathrm{p}<0.05$, n.s: not significant

Further, we also assessed the predictive relevance of the model by using the blindfolding procedure using an omission distance of $\mathrm{D}=7$ (Chin, 1998; Henseler et al., 2009; Tenenhaus et al., 2005). If the $Q^{2}$ value is larger than 0 , the model has predictive relevance for a certain endogenous construct (Hair et al. 2014; Fornell \& Cha, 1994). All $Q^{2}$ values are more than zero suggesting that the model has sufficient predictive relevance (Sarstedt, Ringle \& Hair, 2017). More precisely, BA and SAT have the highest $Q^{2}$ value $(0.486)$, followed by BA $\rightarrow$ RVI $(0.456)$ and BA $\rightarrow$ WOM $(0.419)$. Further analysis of the $Q^{2}$ shows a moderate $Q^{2}$ effect size on the relationship of HA $\rightarrow$ BA (0.252). The $Q^{2}$ effect sizes for $\mathrm{HA} \rightarrow \mathrm{BC}(0.127)$ is rather weak.

As part of the contribution, we also assess the mediation effects on our research model. Based on Table 7, the relationship from HA to BA ( $\left.c^{\prime}\right)$ is weak $(0.067)$ and nonsignificant $(\mathrm{t}=0.054 ; \mathrm{p}=$ 1g.232). We found that the indirect effects is significant $(\mathrm{p}<0.000)$, since the $95 \%$ confidence intervals does not includes zero. The empirical $t$-value of the indirect effect for the HA to BA is 7.977, yielding a p-value of 0.000. As determined earlier, the relationship from HA to BA is weak (0.067) and statically nonsignificant $(\mathrm{t}=0.054, \mathrm{p}=1.232)$. We therefore conclude that $\mathrm{BC}$ fully mediates the HA to BA relationship. The observed VAF also exceeds 80 per cent which implies on additional argument for full mediation (Carrion, Nitzl \& Roldan, 2017). Thus, H2 is supported. 
Table 7: Summary of Mediation Effect Test

\begin{tabular}{lccccccc}
\hline \hline & $\begin{array}{c}\text { Std } \\
\text { Beta }\end{array}$ & $\begin{array}{c}\text { Std } \\
\text { Error }\end{array}$ & $\begin{array}{c}\text { t- } \\
\text { value }\end{array}$ & $\begin{array}{c}\text { p- } \\
\text { value }\end{array}$ & LL & UL & VAF \\
\hline $\begin{array}{l}\text { H1: Direct } \\
\text { effect of HA on }\end{array}$ & 0.067 & 0.054 & 0.054 & $1.232^{\text {n.s }}$ & -0.041 & 0.138 & \\
BA (c') & & & & & & & \\
\hline $\begin{array}{l}\text { H2: Indirect } \\
\text { effect of HA on }\end{array}$ & 0.271 & 0.034 & 7.977 & $0.000^{* *}$ & 0.206 & 0.316 & $80.1 \%$ \\
BA $\left(a_{1} b_{1}\right)$ via & & & & & & & \\
BC
\end{tabular}

Notes: HA: Hotel Attributes; BA: Brand Attachment; BC: Brand Credibility

$* * \mathrm{p}<0.01, * \mathrm{p}<0.05$, n.s: not significant

\section{CONCLUSION}

The study examined the influence of hotel attributes in determining Muslim tourists' hotel choice by considering brand credibility and post-consumption outcomes (i.e., satisfaction, revisit intention and WOM). Our result shows that most of the hypotheses were found to be significant. It is found that brand attachment is positively and directly influence brand satisfaction, supporting for $\mathrm{H} 3$. This is in line with extend literatures that evidence the role of brand attachment on satisfaction (Dennis, Papagiannidis, Alamanos, \& Bourlakis, 2016; Thomson, MacInnis \& Park, 2005). Similarly, the study also found a positive and significant effects of brand attachment on revisit intention, which concurs with previous literatures that evidence the role of brand attachment in repurchase intention (Barreda et al., 2013; Hew et al., 2017), supporting for H4. Likewise, it is found that brand attachment also positively influencing WOM, which corresponds with previous literature that evidence the role of brand attachment in propensity to recommend or WOM (Japutra, Ekinci \& Simkin, 2014). Thus, supporting for H5.

This study also found supports for H6, which suggests brand credibility have positive and significant effect on satisfaction, which concurs with previous literatures (Kozak \& Rimmington, 2000). Similarly, the study also found supports for H7, which posits brand credibility to have positive and direct effect on revisit intention. This is in line with previous studies that evidence the effect of perceived attractiveness on revisit intention (Um et al., 2006). To iterate, perceived attractiveness is one of the dimension that forms brand credibility. Likewise, the study also found support for H8, which suggest brand credibility to have positive and direct effect on WOM, which is in line with previous literatures that suggests brand credibility to be main driver of consumers' word-of-mouth in marketing (Sallam, 2014).

Interestingly, the study found no supports for hypothesis H1, which posits hotel attributes have positive and direct effect on brand attachment, which is contradicted with previous findings. Nevertheless, the study found that Muslim tourists' hotel choice are interrelated in such way that brand credibility fully mediates the effect of hotel attributes on brand attachment, which confirms the expectation that when consumer forms a belief that the hotel is credible, it is anticipated that stronger attachment will be developed through attributes that were offered by the hotel. 


\section{IMPLICATIONS}

\subsection{Theoretical Implications}

This study has helped to demystify the complex relationship of tourists' hotel choice by considering the effects of brand credibility. Indeed, the structural model shows that all path coefficient between hotel attributes, brand credibility and brand attachment are significant. Going deeper into this issue, we have shown that brand credibility fully mediates the relationship between hotel attributes and brand attachment. In other words, the more credible the hotel, the higher the attachment that consumer will develop towards the hotel, which consequently will then lead to post-consumption outcomes. If consumer believe that the hotel can deliver its promise of service quality, it will increase their trustworthiness and they will tend to develop higher affective commitment, since trust in hotel justifies consumer positive feeling towards and reliance on the hotel (Erkman \& Hancer, 2015; Hunt et al., 2006).

\section{2. $\quad$ Practical Implications}

This study analyses the attributes of hotel to provide clues as to what action hotel manager should take to increase consumers' preference for products and services offered by hotel at both strategic and operational levels. Managers need to ensure that the products and services offered by the hotel are technically sound to minimize the risks for the users. Strategically, investing in upgrades and improvements are essential if the hotel want to ensure the increase in repeat business, which is vital for business outcomes. At operational level, hotel managers should ensure the physical facilities of hotels' properties are maintained to the highest standard.

The sustainability of hotels depends mainly on consumer purchase intention. As the hotel industry become more competitive, many hotels compete on price, yet consumers see no difference between the hotels. From a practical perspective, hoteliers should differentiate themselves by finding strategies to strengthen their competitive position. Our findings shown that hotel manager should recognize the key role of hotels' brand credibility in the consumer decision making process. By understanding how brand credibility works in the hotel sector, hotel manager can refine their brand messages in advertising and other marketing executions.

The findings also suggest that hotel attributes still considered as a key determinant for Muslim tourists' in assessing a hotel to stay. Therefore, it must possess an inherent "truth" or "credible" for tourists to develop affection. Hotel managers must monitor the evolution of this information and adjust the advertising, promotional messages, public relations and advising the tour operators to avoid unconformities that may occur.

\subsection{Implication for Future Research}

Firstly, further research could adapt the current study \& test with other sampling design, particularly pertaining to age group. In current study, majority of the respondents aged between 20 to 29 years old. Therefore, the findings were limited to younger generation cohort. It would be interesting if future research could assess consumer with older age group. Past literatures found that older consumers would evaluate their experience with a product at the time of purchase decision, therefore they are more loyal to particular brand than younger consumers (Homburg \& 
Giering, 2001; Lambert-Paudraud et al., 2005 as cited in Goncalves \& Sampaio, 2012). Secondly, future study could attempt to replicate the study and apply it to consumers in specific group pertaining to marital status. Prior literatures evidenced that marital status is significantly important as it shows if the consumers are purchasing / deciding for themselves, spouse, family or children. Therefore, it would be interesting to explore the outcomes of the study considering the individual's status. Perhaps, the application of multi-group analysis could be employed. Thirdly, it is necessary to replicate this study in different national environments. The pattern observed in Malaysia does not necessarily prevail in other countries. Such future research could also provide a clearer picture of the competitive positioning for hotel in the context of comparative cross-sectional research design.

\section{REFERENCES}

Baker, D. A., \& Crompton, J. L. (2000). Quality, satisfaction and behavioral intentions. Annals of Tourism Research, 27(3), 785-804.

Barreda, A., Nusair, K., Okumus, F., \& Bilgihan, A. (2013). Developing a brand structure pyramid model for travel-related online social networks. Tourism Review, 68(4), 49-70.

Battour, M., Battor, M., \& Bhatti, M. A. (2014). Islamic attributes of destination: Construct development and measurement validation, and their impact on tourist satisfaction. International Journal of Tourism Research, 16(6), 556-564. .

Baumgarth, C. (2014). "This theatre is a part of me" contrasting brand attitude and brand attachment as drivers of audience behaviour. Arts Marketing: An International Journal, $4(1 / 2), 87-100$.

Chen, N. C., Dwyer, L., \& Firth, T. (2015). Factors influencing Chinese students' behavior in promoting Australia as a destination for Chinese outbound travel. Journal of Travel and Tourism Marketing, 32(4), 366-381.

Chin, W. W. (1998). The partial least squares approach to structural equation modeling. In G. A. Marcoulides (Ed.), Modern methods for business research (Eds, pp. 295-358). Mahwah: Erlbaum.

Chu, R. K. S., \& Choi, T. (2000). An importance-performance analysis of hotel selection factors in the Hong Kong hotel industry: a comparison of business and leisure travellers. Tourism Management, 21(4), 363-377.

Cronin, J. J., \& Taylor, S. A. (1992). Measuring quality : A reexamination and extension. Journal of Marketing, 56(3), 55-68.

Dennis, C., Papagiannidis, S., Alamanos, E., \& Bourlakis, M. (2016). The role of brand attachment strength in higher education. Journal of Business Research, 69(8), 3049-3057.

Department of Statistics Malaysia. (2018). Domestic Tourism Survey (2017). Retrieved from https://www.dosm.gov.my/v1/index.php?r=column/pdfPrev\&id=dU9zUGtzRG15dXUr ODRUNFQ2cENRQT09

Diamantopoulos, A., \& Siguaw, J. (2006). Formative versus reflective indicators in organizational measure development: A comparison and empirical illustration. British Journal of Management, 17, 263-282.

Diamantopoulos, A., \& Winklhofer, H. M. (2001). Index construction with formative indicators: An alternative to scale development. Journal of Marketing Research, 38(2), 269-277. 
Dolnicar, S., Coltman, T., \& Sharma, R. (2015). Do satisfied tourists really intend to come back? Three concerns with empirical studies of the link between satisfaction and behavioral intention. Journal of Travel Research, 54(2), 152-178.

Doney, P. M., \& Cannon, J. P. (1997). An examination of the nature of trust in buyer-seller relationships. Journal of Marketing, 61(2), 35-51.

Erdem, T., \& Swait, J. (1998). Brand equity as a signaling phenomenon. Journal of Consumer Psychology, 7(2), 131-157.

Erdem, T., \& Swait, J. (2004). Brand credibility, brand consideration, and choice. Journal of Consumer Research, 31(1), 191-198.

Filieri, R., Alguezaui, S., \& McLeay, F. (2015). Why do travelers trust TripAdvisor? Antecedents of trust towards consumer-generated media and its influence on recommendation adoption and word of mouth. Tourism Management, 51, 174-185.

Garbarino, E., \& Johnson, M. S. (1999). The different roles of satisfaction, trust, and commitment in customer relationships. Journal of Marketing, 63(2), 70-87.

Gaur, S. S., Herjanto, H., \& Makkar, M. (2014). Review of emotions research in marketing, 20022013. Journal of Retailing and Consumer Services, 21(6), 917-923.

Gitelson, R. J., \& Crompton, J. L. (1984). Insights into the repeat vacation phenomenon. Annals of Tourism Research, 11(2), 199-217.

Gold, A. H., Malhotra, A., \& Segars, A. H. (2001). Knowledge management: An organizational capabilities perspective. Journal of Management Information Systems, 18(1), 185-214.

Goldenberg, M. A., Klenosky, D. B., O’Leary, J. T., \& Templin, T. J. (2000). A means-end investigation of ropes course experiences. Journal of Leisure Research, 32(2), 208-224.

Guerrero, L. K., \& Afifi, W. A. (1999). Toward a goal-oriented approach for understanding communicative responses to jealousy. Western Journal of Communication, 63(2), 216248.

Gupta, S., \& Saini, G. K. (2018). Information source credibility and job seekers' intention to apply: The mediating role of brands. Global Business Review, 21(2), 1-20.

Gwinner, K. P., Gremler, D. D., \& Bitner, M. J. (1998). Relational benefits in services industries: The customer's perspective. Journal of the Academy of Marketing Science, 26(2), 101114.

Hair, J. F., Hult, G. T. M., Ringle, C. M., \& Sarstedt, M. (2017). A Primer on Partial Least Squares Structural Equation Modeling (PLS-SEM) (2nd ed.). Thousand Oaks: Sage.

Hair, J. F., Ringle, C. M., \& Sarstedt, M. (2011). PLS-SEM : Indeed a silver bullet. Journal of Marketing Theory and Practice, 19(2), 139-151.

Hair, J. F., Sarstedt, M., Hopkins, L., \& Volker, G. K. (2014). Partial least squares structural equation modeling (PLS-SEM). European Business Review, 26(2), 106-121.

Harris, L. C., \& Goode, M. M. H. (2004). The four levels of loyalty and the pivotal role of trust: A study of online service dynamics. Journal of Retailing, 80(2), 139-158.

Hellier, P. K., Geursen, G. M., Carr, R. A., \& Rickard, J. A. (2003). Customer repurchase intention. European Journal of Marketing, 37(11/12), 1762-1800.

Hemsley-Brown, J., \& Alnawas, I. (2016). Service quality and brand loyalty. International Journal of Contemporary Hospitality Management, 28(12), 2771-2794.

Hennig-Thurau, T., Gwinner, K. P., \& Gremler, D. D. (2002). Understanding relationship marketing outcomes. Journal of Service Research, 4(3), 230-247.

Hew, J. J., Badaruddin, M. N. B. A., \& Moorthy, M. K. (2017). Crafting a smartphone repurchase decision making process: Do brand attachment and gender matter? Telematics and Informatics, 34(4), 34-56. 
Jang, S. C., \& Feng, R. (2007). Temporal destination revisit intention: The effects of novelty seeking and satisfaction. Tourism Management, 28(2), 580-590.

Japutra, A., Ekinci, Y., \& Simkin, L. (2014). Exploring brand attachment, its determinants and outcomes. Journal of Strategic Marketing, 22(7), 616-630.

Japutra, A., Ekinci, Y., \& Simkin, L. (2016). Tie the knot: Building stronger consumers' attachment toward a brand. Journal of Strategic Marketing, 26(3), 223-240.

Jeng, S. P. (2016). The influences of airline brand credibility on consumer purchase intentions. Journal of Air Transport Management, 55, 1-8.

Juwaheer, T. D. (2004). Exploring international tourists' perceptions of hotel operations by using a modified SERVQUAL approach - A case study of Mauritius. Managing Service Quality, 14(5), 350-364.

Karjaluoto, H., Munnukka, J., \& Kiuru, K. (2016). Brand love and positive word of mouth: The moderating effects of experience and price. Journal of Product \& Brand Management, 25(6), 527-537.

Kessler, K., \& Kessler, K. (2015). Conceptualizing Mosque Tourism : A central feature of Islamic and Religious Tourism. International Journal of Religious Tourism and Pilgrimage, 3(2), $11-32$.

Kim, W., Ng, C., \& Kim, Y.S.. (2009). Influence of institutional DINESERV on customer satisfaction, return intention, and word-of-mouth. International Journal of Hospitality Management. 28(1), 10-17.

Kim, T., Kim, W. G., \& Kim, H. B. (2009). The effects of perceived justice on recovery satisfaction, trust, word-of-mouth, and revisit intention in upscale hotels. Tourism Management, 30(1), 51-62.

Kozak, M. (2001). Repeater's behavior at two distinct destinations. Annals of Tourism Research, 28(3), 784-807.

Kozak, M., \& Rimmington, M. (2000). Tourist Satisfaction with Mallorca, Spain, as an off-season holiday destination. Journal of Travel Research, 38(3), 260-269.

Kuo, P.J., Zhang, L., \& Cranage, D. A. (2015). What you get is not what you saw: Exploring the impacts of misleading hotel website photos. International Journal of Contemporary Hospitality Management, 27(6), 1301-1319.

Lee, S. H. (2016). Factors influencing the social networking service user's value perception and word of mouth decision of corporate post with special reference to the emotional attachment. Information Technology and Management, 17(1), 15-27.

Lin, Y. T., Chen, S. C., \& Hung, C. S. (2011). The impacts of brand equity, brand attachment, product involvement and repurchase intention on bicycle users. African Journal of Business Management, 5(14), 5910-5919.

Maathuis, O., Rodenburg, J., \& Sikkel, D. (2004). Credibility, emotion or reason? Corporate Reputation Review, 6(4), 333-345.

Matzler, K., Strobl, A., Thurner, N., \& Füller, J. (2015). Switching experience, customer satisfaction, and switching costs in the ICT industry. Journal of Service Management, 26(1), 117-136.

Ohanian, R. (1990). Construction and validation of a scale to measure celebrity endorsers' perceived expertise, trustworthiness, and attractiveness. Journal of Advertising, 19(3), 39-52.

Oppermann, M. (2000). Tourism destination loyalty. Journal of Travel Research, 39(1), 78-84. 
Othman, M., Kamarohim, N., \& Nizam, F. M. (2017). Brand credibility, perceived quality and perceived value: A study of customer satisfaction. International Journal of Economics and Management, $11(\mathrm{~S} 3), 763-775$.

Park, C. W., Macinnis, D. J., Priester, J., \& Eisingerich, A. B. (2010). Brand attachment and brand attitude strength: Conceptual and empirical differentiation of two critical brand equity drivers. Journal of Marketing, 74(6), 1-17.

Planalp, S. (1993). Communication, cognition, and emotion. Communication Monographs, 60(1), 3-9.

Podsakoff, P. M., Mackenzie, S. B., Lee, J., \& Podsakoff, N. P. (2003). Common method biases in behavioral research: A critical review of the literature and recommended remedies. Journal of Applied Psychology, 88(5), 879-903.

Poon, W. C., \& Low, K. (2005). Are travellers satisfied with Malaysian hotels? International Journal of Contemporary Hospitality Management, 17(3), 217-227.

Rai, A., Patnayakuni, R., \& Seth, N. (2006). Firm performance impacts of digitally enabled supply chain integration capabilities. MIS Quarterly, 30(2), 225-246.

Ranaweera, C., \& Prabhu, J. (2003). The influence of satisfaction, trust and switching barriers on customer retention in a continuous purchasing setting. International Journal of Service Industry Management, 14(4), 374-395.

Ryan, S. (2012). Five keys to B2B and B2C marketing success. Business 2 Community. Retrieved from https://www.business2community.com/marketing/five-keys-to-b2b-and-b2cmarketing-success-0305293

Ryu, K., Han, H., \& Jang, S. (Shawn). (2010). Relationships among hedonic and utilitarian values, satisfaction and behavioral intentions in the fast-casual restaurant industry. International Journal of Contemporary Hospitality Management, 22(3), 416-432.

Saad, H. E., Ali, B. N., \& Abdel-Ati, A. M. (2014). Sharia-compliant hotels in Eygpt: Concept and challenges. Advances in Hospitality and Tourism Research, 2(1), 1-15.

Sallam, M. A. (2014). The effects of brand credibility on customers' wom communication: The mediating role of brand commitment. International Journal of Marketing Studies, 6(5), $112-118$.

Santouridis, I., \& Trivellas, P. (2010). Investigating the impact of service quality and customer satisfaction on customer loyalty in mobile telephony in Greece. TQM Journal, 22(3), 330 343.

Sarstedt, M., Ringle, C. M., \& Hair, J. F. (2017). Partial least squares structural equation modeling. In C. Homburg, M. Klarmann, \& A. Vomberg (Eds.), Handbook of Market Research (Eds). Heidelberg: Springer.

Sheeraz, M., Iqbal, N., \& Ahmed, N. (2012). Impact of brand credibility and consumer values on consumer purchase intentions in Pakistan. International Journal of Academic Research in Business and Social Sciences, 2(8), 1-10.

Spry, A., Pappu, R., \& Cornwell, T. B. (2011). Celebrity endorsement, brand credibility and brand equity. European Journal of Marketing, 45(6), 882-909.

Stylos, N., Bellou, V., Andronikidis, A., \& Vassiliadis, C. A. (2017). Linking the dots among destination images, place attachment, and revisit intentions : A study among British and Russian tourists. Tourism Management, 60, 11-12.

Sweeney, J., \& Swait, J. (2008). The effects of brand credibility on customer loyalty. Journal of Retailing and Consumer Services, 15(3), 179-193.

Tae, H. B., \& King, K. W. (2011). Exploring the consequences of brand credibility in services. Journal of Services Marketing, 25(4), 260-272. 
Thomson, M., MacInnis, D. J., \& Park, W.C. (2005). The ties that bind: Measuring the strength of consumers' emotional attachments to brands. Journal of Consumer Psychology, 15(1), 77-91.

Tsung, W. W., Day, R. L., \& Mackay, D. B. (1988). Consumer benefits versus product attributes: An experiemental test. Quaterly Journal of Business and Economics, 27(3), 88-113.

Um, S., Chon, K., \& Ro, Y. H. (2006). Antecedents of revisit intention. Annals of Tourism Research, 33(4), 1141-1158.

Vlachos, P., Theotokis, A., Pramatari, K. \& Vrechopoulos, A. (2010). Consumer-retailer emotional attachment: Some antecedents and the moderating role of attachment anxiety. European Journal of Marketing, 44(9/10), 1478-1499.

Wang, X., \& Yang, Z. (2010). The effect of brand credibility on consumers' brand purchase intention in emerging economies: The moderating role of brand awareness and brand image. Journal of Global Marketing, 23(3), 177-188.

Worsfold, K., Fisher, R., McPhail, R., Francis, M., \& Thomas, A. (2016). Satisfaction, value and intention to return in hotels. International Journal of Contemporary Hospitality Management, 28(11), 2570-2588.

Wray, B., Palmer, A., \& Bejou, D. (1994). Using neural network analysis to evaluate buyer-seller relationships. European Journal of Marketing, 28(10), 32-48.

Yoga, I. (2018). Halal emotional attachment on repurchase intention. Shirkah: Journal of Economics and Business, 3(1), 95-125.

Yoon, Y., \& Uysal, M. (2005). An examination of the effects of motivation and satisfaction on destination loyalty : a structural model. Tourism Management, 26(1), 45-56.

Zboja, J. J., \& Voorhees, C. M. (2006). The impact of brand trust and satisfaction on retailer repurchase intentions. Journal of Services Marketing, 20(6), 381-390. 